\title{
PREVALENCE AND MOLECULAR ANALYSIS OF ANAPLASMA PLATYS IN DOGS IN LARA, VENEZUELA
}

\author{
Haibin Huang'; Ahmet Unver'; Miriam J. Perez²; Nelson G. Orellana²; Yasuko Rikihisa ${ }^{1 *}$ \\ ${ }^{1}$ Department of Veterinary Biosciences, College of Veterinary Medicine, The Ohio State University, Columbus, Ohio 43210-1093, \\ U.S.A.; ${ }^{2}$ Departmento de Medicina Cirugía, Decanato de Ciencias Veterinarias, Universidad Centroccidental "Lisandro \\ Alvarado", Tarabana, Estado Lara, Venezuela
}

Submitted: October 13, 2004; Returned to authors for corrections: August 03, 2005; Approved: September 09, 2005

\begin{abstract}
Blood specimens from clinically normal military dogs and their trainers, in Lara, Venezuela were screened for Anaplasma platys, A. phagocytophilum, or Ehrlichia ewingii using 16S rRNA PCR tests. Sixteen percent (7/ 43) of dog specimens were positive by A. platys PCR test followed by sequencing of the PCR products, and all human blood specimens [25] were negative. All specimens from these dogs and humans were PCR negative for E. ewingii or A. phagocytophilum. Twelve Rhipicephalus sanguineus ticks removed from these dogs were negative for A. platys by reverse transcription PCR test. Almost the entire 16S rRNA gene (1,364 bp) and groESL operon (1,646 bp) sequences of $A$. platys isolated from a dog were determined, revealing that both sequences were closely related to the sequences of an $A$. platys strain detected in $R$. sanguineus ticks from the Democratic Republic of Congo.
\end{abstract}

Key words: $16 \mathrm{~S}$ rRNA, groESL operon, Anaplasma platys, dogs, Venezuela

\section{INTRODUCTION}

Anaplasma platys (formerly, Ehrlichia platys) is an obligatory intracellular bacterium of platelets and is the etiologic agent of canine infectious cyclic thrombocytopenia. The acute phase of infection is characterized by cyclic thrombocytopenia, but infected dogs are not severely ill and rarely show significant hemorrhage (11). Follicular hyperplasia of lymph nodes and plasmacytosis have been observed in the acute phase of infection, and some organs, such as spleen, may develop hemorrhage (3). Clinical cases of canine infectious cyclic thrombocytopenia have been reported throughout the world including the United States (11,17), Greece (15), France (4), Taiwan (8), Spain (21), Southern China (13), Australia (6) and Thailand and Venezuela (24). A. platys cannot be cultured and is even difficult to detect in vivo because of cyclic and often low levels of organisms (10). Currently, the bacterium is poorly known at a molecular level and estimates of prevalence in different areas are often made by immunofluorescence, subject to considerable inaccuracy because of cross-reactions with other species. The PCR test confirmed by DNA sequencing or reverse line blot hybridization (23) is considered to be the most reliable laboratory diagnostic test for A. platys infection. In Venezuela, while there was a report on microscopic observations of blood smear (2), prevalence of $A$. platys infection of dogs has not been determined. Furthermore, microscopic observations of $A$. platys-like organisms in human platelets were reported in Venezuela (1,25), and A. platys infection has been confirmed by PCR in one single dog only (24). The present study, therefore, examined the prevalence of $A$. platys infection in populations at high risk of infection: military dogs, ticks removed from these dogs, and trainers of these dogs in Venezuela, and determined the molecular characteristics of the isolated strains. We also determined the prevalence of infection in these populations for Anaplasma phagocytophilum and Ehrlichia ewingii, both closely related to A. platys and known to infect granulocytes of both dogs and humans $(7,20)$.

*Corresponding Author. Mailing address: Department of Veterinary Biosciences, College of Veterinary Medicine, The Ohio State University, 1925 Coffey Rd., Columbus, OH 43210-1093, USA. Tel.: (+1-614) 292-9677, Fax: (+1-614) 292-6473. E-mail: rikihisa.1@osu.edu 


\section{MATERIALS AND METHODS}

\section{Dog and human blood specimens}

Blood specimens (5- to 10-mL) were collected in EDTA tubes from 23 and 20 military training dogs in Lara State, Venezuela, during December 1999 and April 2000, respectively. Also during December 1999 and April 2000, 20 and 5 blood specimens, respectively, were collected from men who had been involved in training these dogs.

\section{DNA isolation}

DNA was isolated from $200 \mu \mathrm{L}$ of whole blood with a QIAamp blood kit (Qiagen Inc, Valencia, CA, USA), according to the manufacturer's instruction. DNA concentrations were determined by measuring the absorbance at $260 \mathrm{~nm}\left(A_{260}\right)$ with a GeneQuant II RNA and DNA calculator (Pharmacia Biotech Inc., Cambridge, England).

\section{Tick samples and cDNA synthesis}

Rhipicephalus sanguineus ticks (eight males and four engorged females) were collected from military dogs in Lara State, Venezuela, during December 2000. These ticks were dissected with a sterile razor blade by dividing the body along the median plane under a dissecting microscope. The body halves pooled into three groups of four ticks each (two male groups and one female group) were homogenized with a glass homogenizer in TRIzol reagent (GIBCO-BRL, Grand Island, NY, USA), and the total RNA was extracted according to the manufacturer's instruction. The final RNA pellet was resuspended in diethyl pyrocarbonate-treated, distilled deionized sterile water, heated at $70^{\circ} \mathrm{C}$ for $10 \mathrm{~min}$, and reverse transcribed in a $20-\mu \mathrm{L}$ reaction mixture containing $10 \mathrm{mM}$ random hexamer, $0.5 \mathrm{mM}$ each deoxynucleoside triphosphate (dNTP) mixture, $1 \mathrm{U}$ of RNase inhibitor (GIBCO-BRL), and 200 U of SuperScript II RT (GIBCO$\mathrm{BRL}$ ) at $42^{\circ} \mathrm{C}$ for $50 \mathrm{~min}$. The synthesized cDNAs in the final solution were used as template in the PCR.

\section{Detection of $A$. platys in dog and human blood, and tick samples}

The hemi-nested PCR targeting the 16S rRNA gene was performed by using primers EP1, EP2, and EP3 (8). Distilled water was used as negative control. The positive control was A. platys DNA purified from the blood of a dog infected with $A$. platys (kindly provided by Wen-Lan Chang, National Taiwan University, Taiwan). PCR reactions were accomplished on a GeneAmp 9700 thermocycler (Applied Biosystems, Foster City, CA, U.S.A.), using a $50-\mu \mathrm{L}$ reaction mixture containing $1 \times \mathrm{PCR}$ reaction buffer, $3 \mathrm{mM} \mathrm{MgCl}, 0.2 \mathrm{mM}$ each of dNTP mixture, 1.25 U of Taq DNA polymerase (GIBCO-BRL), primers, and template under the following conditions: $5 \mathrm{~min}$ of initial denaturation at $94^{\circ} \mathrm{C}$ followed by 40 cycles of $1 \mathrm{~min}$ of denaturation at $94^{\circ} \mathrm{C}$, $1 \mathrm{~min}$ of annealing at $55^{\circ} \mathrm{C}$, and $1 \mathrm{~min}$ of extension at $72^{\circ} \mathrm{C}$, and $7 \mathrm{~min}$ of extension at $72^{\circ} \mathrm{C}$ after the last cycle. For the first round of PCR, 4-pmol portions each of EP1 and EP3 were used as primers, and $10 \mu \mathrm{L}$ of DNA purified from each blood sample (containing 0.2 to $1.0 \mu \mathrm{g}$ of whole DNA), or $1 \mu \mathrm{L}$ of cDNA from each tick specimen was used as template. For the second round of PCR, 4-pmol each of EP2 and EP3 were used as primers, and $2 \mu \mathrm{L}$ of PCR product from the first-round PCR was used as template. Second-round PCR products at $10 \mu \mathrm{L}$ were electrophoresed in a $1.5 \%$ agarose gel, stained with ethidium bromide, and photographed by using Gel print 2000I (Biophotonics, Ann Arbor, MI, USA).

\section{Detection of E. ewingii and A. phagocytophilum in dog and human blood samples}

The nested PCR targeting the E. ewingii 16S rRNA gene (28) and a single round of PCR targeting A. phagocytophilum $p 44$ multigene family (29) were used to detect $E$. ewingii and $A$. phagocytophilum infection, respectively. The PCR reaction condition was similar to that for A. platys detection.

16S rRNA gene and groESL operon cloning and sequencing

Two primer pairs EP1-EP3 and 750 (5'-TAGTCCACGCTGTA AACG-3')-1400 (5'-CAGCTACCTTGTTACGAC-3') were used to amplify overlapped fragments of the $16 \mathrm{~S}$ rRNA gene. At the time when this work was being performed, no sequence information was available for A. platys groESL gene. Therefore, two primer pairs, designed based on closely related groESL sequence of A. phagocytophilum and A. marginale, GroEL-1F (5'-CATAGTGATGAAGGAGAGTG-3')-GroEL-1R-2 (5'CTTAACTGCTAGCTCGTC-3') and GroEL-2F (5'-TGTAA AGGCGCCTGGTTTCG-3')-GroEL-2R (5'-CGTTCTTA CTAGGAACATCAAC-3'), were used to amplify the overlapped fragments of the groESL operon gene. The reaction condition was similar to that for nested PCR except that $20 \mathrm{p}-\mathrm{moL}$ of each primer and DNA from dog 16 collected in December 1999 were used as template. The PCR products were cloned into the pCRII vector by using a TA cloning kit (Invitrogen, Co., San Diego, CA, USA) according to the manufacturer's instruction. The recombinant DNAs were purified using the Concert rapid Miniprep system (GIBCO-BRL) and sequenced by a dideoxy termination method with a 373 DNA sequencer (Applied Biosystems). The $16 \mathrm{~S}$ rRNA products of the second round PCR from A. platys-positive dog samples were also sequenced. The A. platys $16 \mathrm{~S}$ rRNA and groESL sequences have been deposited into GenBank Database under the accession number AF399917 and AF399916, respectively.

\section{RESULTS}

\section{Prevalence of $A$. platys infection in dogs from Venezuela}

Among 43 dog blood samples, 7 (16\%) [21.7\% (5/23) samples collected in December 1999 and $10.0 \%$ (2/20) samples collected in April 2000] were positive by A. platys 16S rRNA gene specific 
PCR (Fig.1). These dogs were well groomed and no significant clinical signs were noted.

Since $R$. sanguineus ticks were reported to be infected with A. platys $(14,23)$ and RT-PCR based on $16 \mathrm{~S}$ rRNA gene is 100fold more sensitive than PCR based on 16S rRNA gene (9), $R$. sanguineus ticks were examined by A. platys $16 \mathrm{~S}$ rRNA specific RT-PCR. All three pools of 4 ticks each were RT-PCR negative. In addition all the dog and human samples were PCR negative for either E. ewingii or A. phagocytophilum.

\section{Analysis of A. platys strain from Venezuela}

To compare A. platys strain from this geographic region with previously reported strains, sequences of 16S rRNA and groESL genes were determined. Sequences of the second-round PCR products of $16 \mathrm{~S}$ rRNA (348 bp) from all seven A. platys PCR-positive samples were identical. Thus, a nearly entire sequence $(1,364 \mathrm{bp})$ of the $16 \mathrm{~S}$ rRNA gene was obtained from the dog blood sample \#16 (designated as A. platys Lara) collected in December 1999. Nucleotide differences between this new sequence and other $A$. platys $16 \mathrm{~S}$ rRNA gene sequences currently available in the GenBank database are shown in Table 1. Strain polymorphisms were seen throughout the gene in $14 / 1,330$ positions. The alignment of $A$. platys $16 \mathrm{~S}$ rRNA gene sequences $(1,330 \mathrm{bp})$ on database showed that A. platys Lara 16S rRNA gene was closest to that of strain Sommieres from France and strain Okinawa from Japan (1 bp substitution). In addition, $16 \mathrm{~S}$ rRNA gene sequences of strain Sommieres from France and strain Okinawa from Japan were identical. Lara's

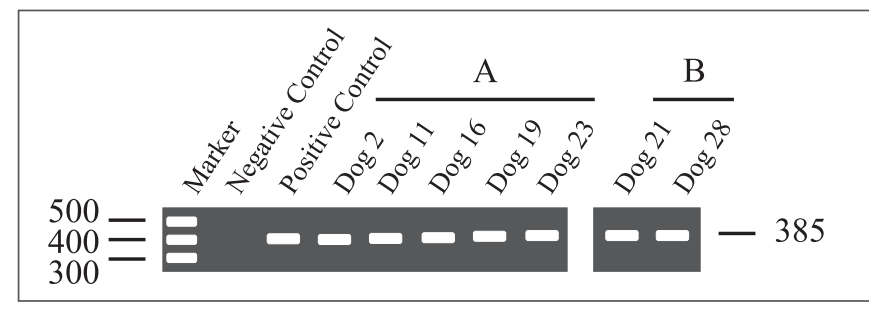

Figure 1. Agarose gel electrophoresis of the second round of A. platys 16S rRNA nested PCR products of positive specimens. Group A, dog samples collected in December, 1999; Group B, dog samples collected in April, 2000. Marker, $1 \mathrm{~kb}$ plus DNA marker (GIBCO-BRL); negative control, water was used as template; positive control, A. platys DNA purified from the blood of an A. platys infected dog in Taiwan; numbers on the left and right indicate molecular sizes in base pairs. $1.5 \%$ agarose.

strain 16S rRNA sequence had 3 bp substitutions when compared to $1,330 \mathrm{bp}$ of the strain Venezuela, obtained from a dog in Maracaibo, Venezuela.

A partial groESL operon sequence (1,646 bp) of A. platys Lara was also obtained. The stop codon for GroES and the start codon for GroEL were deduced based on alignment of all groESL operon sequence of other Anaplasma species available at GenBank database. The groESL sequence in the present study encoded the C-terminal 6 amino acids of GroES protein, a 51-bp intergenic space, and 524 amino acids of GroEL protein. The

Table 1. Nucleotide sequence differences among 16S rRNA gene from different strains of A. platys.

\begin{tabular}{|c|c|c|c|c|c|c|c|c|c|c|c|c|c|c|}
\hline \multirow[t]{2}{*}{ Strains } & \multicolumn{14}{|c|}{ Nucleotide Positions ${ }^{\mathrm{a}}$} \\
\hline & 213 & $241-242$ & $452-453$ & 737 & $824-825$ & $875-876$ & 877 & $927-928$ & 1017 & 1081 & 1237 & 1248 & 1289 & 1405 \\
\hline A. platys Louisana ${ }^{\mathrm{b}}$ & $\mathrm{T}$ & - & - & $\mathrm{T}$ & - & - & $\mathrm{C}$ & - & G & G & A & $\mathrm{T}$ & G & $\mathrm{T}$ \\
\hline A. platys Lara ${ }^{\mathrm{c}}$ & - & G & - & G & - & $\mathrm{C}$ & G & - & - & - & - & - & $\mathrm{T}$ & - \\
\hline A. platys Venezuela ${ }^{\mathrm{d}}$ & $\mathrm{C}$ & A & $\bullet$ & $\mathrm{G}$ & $\bullet$ & $\mathrm{C}$ & $\mathrm{G}$ & $\bullet$ & $\bullet$ & - & $\mathrm{G}$ & - & $\mathrm{T}$ & $\bullet$ \\
\hline A. platys Thailand & $\bullet$ & $\mathrm{A}$ & - & $\mathrm{G}$ & $\bullet$ & $\mathrm{C}$ & $\mathrm{G}$ & $\bullet$ & - & A & - & $\mathrm{C}$ & $\mathrm{T}$ & $\bullet$ \\
\hline A. platys Gzh981 & $\bullet$ & $\mathrm{A}$ & $\mathrm{C}$ & G & $\bullet$ & $\mathrm{C}$ & G & $\mathrm{T}$ & - & - & $\bullet$ & - & $\mathrm{T}$ & $\bullet$ \\
\hline A. platys Sommieres & $\bullet$ & $\mathrm{A}$ & - & G & $\bullet$ & $\mathrm{C}$ & G & - & $\bullet$ & $\bullet$ & - & - & $\mathrm{T}$ & $\bullet$ \\
\hline A. platys Okinawa ${ }^{\mathrm{h}}$ & $\bullet$ & $\mathrm{A}$ & $\bullet$ & G & - & $\mathrm{C}$ & G & $\bullet$ & $\bullet$ & $\bullet$ & $\bullet$ & $\bullet$ & $\mathrm{T}$ & $\bullet$ \\
\hline A. platys Okinawa $1^{\mathrm{i}}$ & $\bullet$ & A & $\mathrm{C}$ & G & • & $\mathrm{C}$ & $\mathrm{G}$ & • & • & • & • & • & $\mathrm{T}$ & - \\
\hline A. platys Spain & - & A & - & $\mathrm{G}$ & G & $\mathrm{C}$ & G & - & - & - & - & - & $\mathrm{T}$ & - \\
\hline
\end{tabular}

a The number represents the nucleotide position of the type strain (A. platys ${ }^{\mathrm{T}}$ Louisiana, GenBank accession number M82801); where two nucleotide positions are shown, some strains had an insertion; $\bullet$, same base as the type strain; - - deletion. The region (nucleotide position 70 1409 of the type strain) that can be aligned unambiguously (1,340 bp) were compared; ${ }^{b}$ A. platys type strain from a dog in the U.S.A. (GenBank accession number: M82801); ${ }^{\mathrm{C}}$ Sequence obtained in this study from a Venezuelan dog (GenBank accession number: AF399917); ${ }^{\mathrm{d}}$ A. platys from dogs in Venezuela (GenBank accession number: AF287153); ${ }^{\mathrm{e}}$ A. platys from dogs in Thailand (GenBank accession number: AF286699); ${ }_{\mathrm{f}}^{\mathrm{f}}$ A. platys from a dog in China (GenBank accession number: AF156784); ${ }_{\mathrm{g}}^{\mathrm{A}}$ A. platys from a dog in France Sommieres (GenBank accession number: AF303467); ${ }^{\text {h }}$ A. platys from a dog in Okinawa, Japan (GenBank accession number: AY077619); ${ }^{i}$ A. platys from a dog in Okinawa, Japan (GenBank accession number: AF536828); ${ }^{\mathrm{H}}$ A. platys from a dog in Spain (GenBank accession number: AY530806). 
groEL sequence which we obtained, covered $95.3 \%$ of the complete groEL coding sequence of $E$. chaffeensis (GenBank accession no. AAB49805). Only four A. platys groESL operon sequences are currently available at GenBank. However, groEL sequence from Louisana strain from the U.S.A. (GenBank accession no. AY008300) is $1070 \mathrm{bp}$, too short to be included in this comparison. The remaining three sequences were aligned with Lara groESL operon sequence and the differences between these sequences were summarized in Table 2. Lara strain groESL sequence $(1,646 \mathrm{bp})$ was identical to that of RDC strain from Democratic Republic of Congo. Compared to Sommieres strain from France, Lara groESL had 1 bp substitution and resulted in one amino acid change in GroEL $\left(9^{\text {th }}\right.$ amino acid from the first methionine) from lysine in Sommieres strain to glutamic acid in Lara strain. Lara groESL had 3 bp substitutions when compared to that of Okinawa strain and resulted in one amino acid change at the same position. Sequences (51-bp) of groES and groEL intergenic region were identical among four strains (RDC, Sommieres, Okinawa, and Lara).

Table 2. Nucleotide sequence differences among groESL from different strains of A. platys.

\begin{tabular}{|c|c|c|c|}
\hline \multirow[t]{2}{*}{ Strains } & \multicolumn{3}{|c|}{ Nucleotide Positions ${ }^{a}$} \\
\hline & 117 & 341 & 1472 \\
\hline A. platys Sommieres ${ }^{\mathrm{b}}$ & A & $\mathrm{G}$ & $\mathrm{T}$ \\
\hline A. platys $\mathrm{Lara}^{\mathrm{c}}$ & $\mathrm{G}$ & $\bullet$ & - \\
\hline A. platys $\mathrm{RDC}^{\mathrm{d}}$ & $\mathrm{G}$ & $\bullet$ & - \\
\hline A. platys Okinawa ${ }^{\mathrm{e}}$ & $\bullet$ & A & $\mathrm{C}$ \\
\hline A. platys $^{\mathrm{T}}$ Louisiana $^{\mathrm{f}}$ & l & $\bullet$ & / \\
\hline
\end{tabular}

${ }^{\text {a }}$ The number represents the nucleotide position of A. platys Sommieres strain, GenBank accession number AY0441621; •, same base with Sommieres strain; /, sequence not available. The region (nucleotide position 19-1664 of Sommieres strain) that can be aligned unambiguously (1,646 bp) were compared; ${ }^{\mathrm{b}}$ A. platys from a dog in France Sommieres (GenBank accession number: AY044161); ${ }^{\mathrm{c}}$ Sequence obtained in this study from a Venezuelan dog (GenBank accession number: AF399916); ${ }^{\mathrm{d}}$ A. platys from Rhipicephalus sanguineus ticks in Democratic Republic of Congo (RDC) (GenBank accession number: AF478129); ${ }^{\mathrm{e}}$ A. platys from a dog in Okinawa, Japan (GenBank accession number: AY077621); ${ }^{\mathrm{f}}$ A. platys from a dog in Louisiana (primer sequences: $20 \mathrm{bp}$ at 5 ' end and 23 bp at 3' end, were removed) (GenBank accession number: AY008300).

\section{DISCUSSION}

To our knowledge, the present study is the first report on $A$. platys prevalence in South America determined by PCR. PCR positive rate was $16 \%$ in clinically normal dogs in Lara, Venezuela. PCR test was confirmed by sequencing the all PCR positive products. The results indicate a high prevalence of subclinical infection of dogs. There have been only two PCR-based A. platys prevalence reports. In one kennel in North Carolina, USA, $33 \%$ of 27 dogs were A. platys PCR-positive (16). In Okinawa, Japan, $32 \%$ of 200 stray dogs were positive by A. platys-specific PCR (18). On the other hand, the indirect fluorescent antibody (IFA) test using blood from an experimentally infected dog as antigen in Florida, indicated that 5\% of 100 clinically normal dogs were positive, while $35 \%$ of 26 thrombocytopenic dogs were seropositive (10). In Louisiana, USA, $50 \%$ of $86 \mathrm{dogs}$ tested were IFA positive (12). In eastern North Carolina, USA, $68 \%$ of the 50 tested dogs had low platelet counts and $74 \%$ were serologically positive (5).

The 16S rRNA sequence of strain Lara was different from another Venezuela strain from Maracaibo, suggesting that there are at least two strains of A. platys in Venezuela. Interestingly, Lara strain's groESL sequence was found to be identical to the sequence of the RDC strain from $R$. sanguineus ticks collected from dogs in Democratic Republic of Congo. The short (732 bp) partial 16S rRNA sequence of the RDC strain (GenBank accession no. AF478131) is available for comparison. The sequence of 16S rRNA gene of the RDC strain (from nucleotide position 1 to $726 \mathrm{bp}$ of $16 \mathrm{~S}$ rRNA sequence of the strain Lara) was $100 \%$ identical to that of Lara strain. The unusual $6 \mathrm{bp}$ sequence at the 3' end of the partial 16S rRNA gene of the RDC strain does not match with any 16S rRNA sequence in the Anaplamaceae family. These data suggest that A. platys strains are not geographically segregated. Close similarity between the 16S rRNA gene and groESL sequences of strain Sommieres from France and strain Okinawa from Japan, also supports this hypothesis, although sequence analysis of additional genes is necessary to confirm this observation.

The dogs of the present study were previously tested for $E$. canis infection and the detected infection rate was $31 \%$ (26). Only two samples (dog 23 in December 1999 and dog 21 in April 2000) were found to be infected by E. canis and A. platys. Remaining five dogs were infected only with $A$. platys. The rate of A. platys-infected dogs that were coinfected with $E$. canis was 29\% (2/7). Previously, a dog from Maracaibo, Venezuela was reported to be PCR positive for three pathogens: A. platys, A. phagocytophilum, and E. canis (24). Another case of a dog coinfected with $A$. platys and $E$. canis was reported in China (13). These data suggest that $A$. platys and $E$. canis may share the same vector. A. platys DNA was detected in $R$. sanguineus ticks in Japan (14) and Spain (23). However, A. platys 16S rRNA was undetectable in three $R$. sanguineus tick pools in the present study, although the same three pools of tick specimens were all positive for E. canis $16 \mathrm{~S}$ rRNA (26). Experimental A. platys transmission by $R$. sanguineus ticks was reported to be unsuccessful (22). These results suggest that $A$. platys tick infection level is very low or $R$. sanguineus is not an effective vector for transmitting A. platys. It is also possible that other 
tick species are involved in A. platys transmission. In fact, a 16S rRNA gene sequence of Ehrlichia sp. Omatjenne (GenBank accession no. U54806) closely related to A. platys Lara strain (99.3\% identity, 4 bp substitution and 1 bp deletion/1,330 bp in Ehrlichia sp. Omatjenne) was found in Hyalomma truncatum ticks in Africa. Alternatively, one of reasons for the A. platys 16S rRNA RT-PCR negative result may be due to very small number of $R$. sanguineus ticks collected and tested in the present study.

Dogs are reported to be infected with several rickettsial species in the family Anaplasmataceae: monocyte-tropic species (E. canis, E. chaffeensis, Neorickettsia helminthoeca, and Neorickettsia risticii), granulocyte-tropic species (E. ewingii and A. phagocytophilum), and platelet-tropic A. platys (20). In the USA, E. chaffeensis, E. ewingii, and A. phagocytophilum are known to cause human ehrlichioses (20), and dogs may serve as sentinel of infection with these organisms. In Venezuela dogs are heavily infected with $E$. canis and infection of humans with the same strain of $E$. canis has been confirmed by culture isolation of $E$. canis of the identical 16S rRNA gene sequences from a human and a dog, respectively $(19,26)$. In the present study, however, all human and dog specimens tested were negative for E. ewingii or A. phagocytophilum infection. Thus, in Lara, Venezuela, these infections may not be prevalent. Despite the reports of rickettsiae-like organisms in human platelets in Venezuela $(1,25)$, there has been no evidence for human infection with $A$. platys in the present study. Further studies are needed to clarify potential human infection with $A$. platys in Venezuela.

\section{ACKNOWLEDGEMENTS}

This research was supported by a grant R01AI47407 from the National Institutes of Health and Ohio State University Faculty International Travel grant. We appreciate Venezuelan Military Center for Canine Training for collaboration. Authors appreciate Dr. Roger W. Stich at the Ohio State University, and Dr. James E. Keirans, Georgia Southern University for the tick species identification. We thank Wen-Lan Chang for providing the A. platys positive control DNA and A. platys nested PCR primers EP1, EP2 and EP3.

\section{RESUMO}

\section{Prevalência e análise molecular de Anaplasma platys em cães da Venezuela}

Amostras de sangue coletadas de cães clinicamente sadios pertencentes ao exército da Venezuela e de seus treinadores foram analisadas pela técnica de PCR $16 \mathrm{~S}$ rRNA específica para Anaplasma platys, A. phagocytophilum ou Ehrlichia ewingii. Dezesseis por cento (7/43) dos cães foram positivos, enquanto que todas as amostras de origem humana [25] foram negativas para A. platys. Todas as amostras, tanto de humanos quanto de caninos, foram negativas para $E$. ewingii ou $A$. phagocytophilum. Doze carrapatos da espécie Rhipicephalus sanguineus, coletados dos cães, foram negativos para A. platys pelo teste de PCR de transcrição reversa. As seqüências quase inteiras do gene $16 \mathrm{~S}$ rRNA (1.364 pb) e do operon $\operatorname{groESL}(1.646$ pb) de A. platys isolado de um cão foram determinadas, revelando que ambas as seqüências estão estreitamente relacionadas às seqüências de $A$. platys detectadas em carrapatos $R$. sanguineus na República Democrática do Congo.

Palavras-chave: 16S rRNA, groESL operon, Anaplasma platys, cães, Venezuela

\section{REFERENCES}

1. Arraga-Alvarado, C.; Palmar, M.; Parra, O.; Salas, P. Fine structural characterisation of a Rickettsia-like organism in human platelets from patients with symptoms of ehrlichiosis. J. Med. Microbiol., 48, 991-997, 1999

2. Arraga-Alvarado, C.; Palmar, M.; Parra, O.; Salas, P. Ehrlichia platys (Anaplasma platys) in dogs from Maracaibo, Venezuela: an ultrastructural study of experimental and natural infections. Vet. Pathol., 40,149-156, 2003.

3. Baker, D.C.; Simpson, M.; Gaunt, S.D.; Corstvet, R.E. Acute Ehrlichia platys infection in the dog. Vet. Pathol., 24, 449-453, 1987.

4. Beaufils, J.P. Un syndromes' accompagnant d'inclusions plaquettaires Chez le Chien, dans la region de montpellier. Description et comparaison aux affections engendrees par Ehrlichia canis et Ehrlichia platys, 1985. (Ph.D. Thesis. Ecole Nationale Veter de Toulouse).

5. Bradfield, J.F.; Vore, S.J.; Pryor, W.H. Jr. Ehrlichia platys infection in dogs. Lab. Anim. Sci., 46, 565-568, 1996

6. Brown, G.K.; Martin, A.R.; Roberts, T.K.; Aitken, R.J. Detection of Ehrlichia platys in dogs in Australia. Aust. Vet. J., 79, 554-558, 2001.

7. Buller, R.S.; Arens, M.; Hmiel, S.P.; Paddock, C.D.; Sumner, J.W.; Rikhisa, Y.; Unver, A.; Gaudreault-Keener, M.; Manian, F.A.; Liddell, A.M.; Schmulewitz, N.; Storch, G.A. Ehrlichia ewingii, a newly recognized agent of human ehrlichiosis. N. Engl. J. Med., 341, 148$155,1999$.

8. Chang, W.L.; Pan, M.J. Specific amplification of Ehrlichia platys DNA from blood specimens by two-step PCR. J. Clin. Microbiol., 34, 3142-3146, 1996.

9. Felek, S.; Unver A.; Stich, R.W.; Rikihisa, Y. Sensitive detection of Ehrlichia chaffeensis in cell culture, blood, and tick specimens by reverse transcription-PCR. J. Clin. Microbiol., 39, 460-463, 2001

10. French, T.W.; Harvey, J.W. Serologic diagnosis of infectious cyclic thrombocytopenia in dogs using an indirect fluorescent antibody test. Am. J. Vet. Res., 44, 2407-2411, 1983.

11. Harvey, J.W.; Simpson, C.F.; Gaskin, J.M. Cyclic thrombocytopenia induced by a Rickettsia-like agent in dogs. J. Infect. Dis., 137, 182 188,1978

12. Hoskins, J.D.; Breitschwerdt, E.B.; Gaunt, S.D.; French, T.W.; Burgdorfer, W. Antibodies to Ehrlichia canis, Ehrlichia platys, and spotted fever group rickettsiae in Louisiana dogs. J. Vet. Intern. Med., 2, 55-59, 1988.

13. Hua, P.; Yuhai, M.; Shide, T.; Yang, S.; Bohai, W.; Xiangrui, C. Canine ehrlichiosis caused simultaneously by Ehrlichia canis and Ehrlichia platys. Microbiol. Immunol., 44, 737-739, 2000. 
14. Inokuma, H.; Raoult, D.; Brouqui, P. Detection of Ehrlichia platys DNA in brown dog ticks (Rhipicephalus sanguineus) in Okinawa Island, Japan. J. Clin. Microbiol., 38, 4219-4221, 2000.

15. Kontos, V.I.; Papadopoulos, O.; French, T.W. Natural and experimental canine infections with a Greek strain of Ehrlichia platys. Vet. Clin. Pathol., 20, 101-105, 1991.

16. Kordick, S.K.; Breitschwerdt, E.B.; Hegarty, B.C.; Southwick, K.L.; Colitz, C.M.; Hancock, S.I.; Bradley, J.M.; Rumbough, R.; McPherson, J.T.; MacCormack, J.N. Coinfection with multiple tick-borne pathogens in a Walker Hound kennel in North Carolina. J. Clin. Microbiol., 37, 2631-2638, 1999.

17. Mathew, J.S.; Ewing, S.A.; Murphy, G.L.; Kocan, K.M.; Corstvet, R.E.; Fox, J.C. Characterization of a new isolate of Ehrlichia platys (Order Rickettsiales) using electron microscopy and polymerase chain reaction. Vet. Parasitol., 68, 1-10, 1997.

18. Motoi, Y.; Satoh, H.; Inokuma, H.; Kiyuuna, T.; Muramatsu, Y.; Ueno, H.; Morita, C. First detection of Ehrlichia platys in dogs and ticks in Okinawa, Japan. Microbiol. Immunol., 45, 89-91, 2001.

19. Perez, M.; Rikihisa, Y.; Wen, B. Ehrlichia canis-like agent isolated from a man in Venezuela: antigenic and genetic characterization. $J$. Clin. Microbiol., 34, 2133-2139, 1996.

20. Rikihisa, Y. Diagnosis of emerging ehrlichial diseases of dogs, horses, and humans. J. Vet. Intern. Med., 14, 250-251, 2000.

21. Sainz, A.; Amusategui, I.; Tesouro, M.A. Ehrlichia platys infection and disease in dogs in Spain. J. Vet. Diagn. Invest., 11, 382-384, 1999.

22. Simpson, R.M.; Gaunt, S.D.; Hair, J.A.; Kocan, K.M.; Henk, W.G.; Casey, H.W. Evaluation of Rhipicephalus sanguineus as a potential biologic vector of Ehrlichia platys. Am. J. Vet. Res., 52, 1537-1541, 1991.
23. Sparagano, O.A.; de Vos, A.P.; Paoletti, B.; Camma, C.; de Santis, P.; Otranto, D.; Giangaspero, A. Molecular detection of Anaplasma platys in dogs using polymerase chain reaction and reverse line blot hybridization. J. Vet. Diagn. Invest., 15, 527-534, 2003.

24. Suksawat, J.; Pitulle, C.; Arraga-Alvarado, C.; Madrigal, K.; Hancock, S.I.; Breitschwerdt, E.B. Coinfection with three Ehrlichia species in dogs from Thailand and Venezuela with emphasis on consideration of $16 \mathrm{~S}$ ribosomal DNA secondary structure. J. Clin. Microbiol., 39, 90-93, 2001.

25. Tami, I.; Martinez, I.; Tami, M.; Redondo, M.C.; Finol, H.; Simonovis, N. Identification of Ehrlichia species in blood smear. Infect. Dis. Clin. Prac., 5, 555-557, 1996.

26. Unver, A.; Perez, M.; Orellana, N.; Huang, H.; Rikihisa, Y. Molecular and antigenic comparison of Ehrlichia canis isolates from dogs, ticks, and a human in Venezuela. J. Clin. Microbiol., 39, 2788-2793, 2001.

27. Unver, A.; Rikihisa, Y.; Kawahara, M.; Yamamoto, S. Analysis of 16S rRNA gene sequences of Ehrlichia canis, Anaplasma platys, and Wolbachia species from canine blood in Japan. Ann. N. Y. Acad. Sci., 990, 692-698, 2003

28. Warner, C.K.; Dawson, J.E. Genus- and species-level identification of Ehrlichia species by PCR and sequencing. In: Persing, D.H. (ed). PCR protocols for emerging infectious diseases: a supplement to Diagnostic Molecular Microbiology: Principles and Applications. ASM Press, Washington, 1996, p.100-105.

29. Zhi, N.; Ohashi, N.; Rikihisa, Y. Multiple $p 44$ genes encoding major outer membrane proteins are expressed in the human granulocytic ehrlichiosis agent. J. Biol. Chem., 274, 17828-17836, 1999. 